\title{
Seeking Souls, Selling Salvation: A History of the Modern Megachurch
}

\author{
Charity Rakestraw
}

\section{1 \\ Introduction}

A fake shark - bathed in neon purples and blues - menaces the stage as pastor Ed Young, Jr., steps out to the standing ovation of his thousands of congregants. Church has started. Young, in his fifties with youthfully coiffed hair and tidy in a slick-grey suit, begins with a viral toddler song. He leads his audience in a call-and-response: "baby shark, bum bum bum bum bum, teenage shark, bum bum bum bum bum...." (Young 2011). As he shakes his hips and moves his arms in a chomping motion, Young draws them in. The camera pans to the audience, all wiggling their hips and clapping their arms to follow. Young is an entertainer. He is also a social media personality, a rap-music satirist, and a man of God. The lead pastor of one of the largest megachurches in Dallas, Young has many fans. His primary congregation at Fellowship Church in Grapevine has an estimated Sunday attendance of 20,000 , a figure that does not include the thousands of other members and visitors who frequent the seven satellite campuses or watch his sermon feeds on the "Fellowship Live" internet broadcast each week. ${ }^{1}$ On this particular Sunday in August of 2011, Young unveiled a sermon series called "Shark Weak". A puny reference to the Discovery Channel predator fish programme, the series spins popular television into spiritual selfhelp lessons so that congregants might navigate metaphorical 'sharks' in their lives. This up-beat preaching style, complete with familiar popular culture reference and a therapeutic message, reflects just some of the major trends that define modern megachurches. The novelty shark notwithstanding, this entire spectacle is rooted within the historical narrative of the megachurch and is a product of centuries of evangelical evolution.

Megachurches like Ed Young, Jr.'s, did not simply materialise. They did not spring up in shopping centres and off of interstates without precursor or precedent. Megachurches are modern manifestations of eighteenth and nineteenth century revivalism, early-twentieth century innovations in religious

1 Internet site, https://fellowshipchurch.com. Accessed 7/1/2018. 
mass-media, mid-twentieth century church marketing techniques, and the rise of seeker-sensitive models in the late-twentieth century. The 1830 s theatrics of Charles Grandison Finney, the 1930s innovations of Aimee Semple McPherson, the 1950s and 196os televangelism work of Robert Schuller, and the 1970s seeker-sensitive model of Bill Hybels all contributed to the corporatisation and commodification of religion in recent decades. ${ }^{2}$ At the turn of the twentieth century, as a result of the culmination of renewed revivalism, significant technological advances, and the market-driven church growth movement, pastors like Young built mammoth suburban and exurban churches that bring in tens of thousands of congregants - or consumers, as noted in some megachurch materials (Sargeant 2000: 42-43). These churches often look more like theme parks or shopping centres than traditional chapels, including attractions like go-kart rinks and food courts. Fellowship Church is just one example of the now thousands of American megachurches that have exported their brand of worship to national and international audiences. They are typically characterised by rapid church growth, an integration of technology and entertainment into their services, and a charismatic pastor who is central to the image of the congregation.

"Megachurches are not an entirely new phenomenon", Scott Thumma and David Travis (2007: 6) insist in Beyond Megachurch Myths. In this defining work for seminarians and pastors seeking to understand (and perhaps replicate) current trends, the authors place megachurches within the more recent history of the late-twentieth century. For several decades, congregations have experimented with the use of small groups, marketing, and personality-driven pastoring, all characteristics that have contributed to the rise of enormous congregations. This type of large church with a weekend attendance of over 2,000 has become increasingly popular since the 1970s, as many Protestants gravitated towards sensational services and a church-growth mindset.

Many of these churches have broken traditional moulds to provide upbeat music instead of sober hymns, pop-culture preaching instead of fire-andbrimstone sermonising, engaging children's and youth ministries, food courts, gift shops, and even car bays for oil changes. All of these features have expanded membership and viewership for services that are televised and streamed on the internet. Since 1970, the number of US megachurches has expanded from an estimated 150 to over 1500 (Thumma and Travis 2007: 7). ${ }^{3}$ These churches

2 Democratisation of religion also played a large role in establishing and expanding the religious marketplace in the nineteenth century. For additional information on the relationship between democratisation and religious movements in the United States, see Hatch (1989).

3 Internet site, http://hirr.hartsem.edu/megachurch/megastoday_profile.html. Accessed $8 / 28 / 2018$. 
sprouted on fertile soil, borrowing from a longer history of evangelical preaching, revival spirit, and Protestant adaptations to contemporary shifts in culture and the religious marketplace.

While there is agreement that megachurches are moored in a longer Christian history, scholars continue to debate their origins and antecedents. Some trace them back significantly earlier than Thumma and Travis (2007: 6), who focus more on "the rapid proliferation of these churches since the $1970 \mathrm{~s}$ " as "a distinctive social phenomenon". Sociologist David Eagle (2015:590) contends that Protestants have had the 'impulse' to build large churches since the sixteenth century and the Edict of Nantes, which granted Protestants in France rights and allowed them to construct their own buildings. Architects then began drafting plans for structures that could hold thousands of congregants. In the seventeenth century, these plans influenced the building of church structures like the Temple de Charenton near Paris. Eagle directly connects that the Institutional Church Movement of the nineteenth and twentieth centuries to the direction of Protestantism that resulted in these most recent large congregations. Ultimately, he argues, they are "nothing new", but rather the 'newness' they project is more a marketing ploy. Eagle asserts that "[n]ewness and innovation have long-possessed an enduring sense of appeal to middle and upper middle class Americans - the group to which these [megachurch] pastors wished to appeal" (Eagle 2015: 590-591).

Other scholars describe megachurches as more distant relatives of earlier American religious groups who did not share their scale. In their architectural history of evangelical churches, Anne C. Loveland and Otis B. Wheeler (2003: 5) argue that the Puritan meetinghouse, devised in the Massachusetts Bay colony after the sect's arrival in 1630 , is " $t \mathrm{t}]$ he earliest American antecedent of the late-twentieth-century evangelical megachurches". The relationship between meetinghouses and megachurches is not size (meetinghouse attendance did not number in the thousands) but, instead, rests on the rejection of orthodoxy. Puritans denounced Anglican architectural and liturgical styles in order to focus their attention on the functional needs of the community and congregants. In other words, like modern-day megachurches, their structures responded to the "purposes, beliefs, and activities of the people who used them" (Benes 2012; Loveland and Wheeler 2003: 5). Unlike typical megachurches, however, the Puritan sites were plain, without ornamentation, and remained mostly functional and not recreational. 
Earlier temples and meetinghouses portended the spacious, multi-purpose churches of the twentieth and twenty-first century in various ways, but the 'Second Reformation' of today's Christian experience has its most clear and discernible origins in revivalism. It was not until revivalism took hold in the eighteenth century that religious leaders began to intentionally construct spaces for the masses that would allow for more emotionally charged and theatrical teachings and worship. The path-breaking evangelist George Whitefield, for instance, spearheaded revivalism and developed preaching techniques that upended traditional teachings. During the 1740 s and 1750 s, Whitefield transformed Protestantism by rejecting the trappings of Anglicanism, advertising his open-air meetings to the masses, and developing his own tabernacle design - all styles that the British minister introduced to America during the Great Awakening. The architecture of these structures underscored the importance of the preacher, with "lantern-shaped" roofs that would allow for additional levels of pews with views of the pulpit and for louder acoustics (Eagle 2015: 592-594). In his tabernacles and outdoor meetings, Whitefield also engineered a successful formula for emotional, personality-driven preaching. Megachurch scholars Shayne Lee and Phillip Luke Sinitiere (2009: 14) argue that, for this reason, he was "America's first religious celebrity and superstar" as he "introduced a stimulating brand of Christianity that captured the New World's attention like never before and set the template for successive revivalists". His ability to not only instruct and inspire but also to entertain set Whitefield apart from his contemporaries and led to immense popularity and mass attendance. The "divine dramatist" cultivated an affected style of oratory that more resembled acting and theatrical performance than the traditional, recycled rituals and monotone messages of other clergymen (Stout 1991). This flair put the preacher at the centre of church culture, a tactic that his successors adopted and adapted to their own success (Lambert 2008: $56-57,89-91,128-$ 129). ${ }^{4}$ This form of religious marketing fed future trends of preaching as performance in order to attract large crowds.

Religious theatre became characteristic of revivalism and the religious marketplace of nineteenth-century America, fuelling the development of sizeable church structures with larger-than-life preachers. ${ }^{5}$ Camp meetings served as

4 Lambert draws a line from Whitefield to Charles Grandison Finney, Billy Sunday, and Billy Graham.

5 In his study of the religious marketplace in the United States, Moore (1995: 6) describes the tension between religious leaders and the "marketplace of culture", as they both combatted 
the first sites of revivals in the early-nineteenth century, where thousands of Americans would gather to hear the booming voices of Protestant ministers who urged them to feel the call of the spirit and accept salvation. Many of these preachers initially eschewed the idea that they engaged in 'stage techniques' because of the stigma of the of the sinful secular theatre. The lively Methodist itinerants Lorenzo Dow and Peter Cartwright, for instance, "aroused crowds" because they "used common speech; they told stories and sang songs; they prayed on their knees" (Moore 1995: 39). Eventually, ministers admitted to cultivating a stage-craft in order to captivate their audiences and obtain their conversion and some published "practical guides" on effective preaching techniques (Moore 1995: 50). Much like today's megachurch pastors who entertain and inspire their congregations with animated performances, revival preachers riveted spectators with stories, songs, and direct exhortations.

The most famous of these revival preachers, Charles Grandison Finney abandoned his career as a lawyer in the 1820 s to become a full-time minister, combining the dramatic style of predecessors like Whitefield with an unapologetic penchant for the stage. ${ }^{6}$ While he abhorred the secular theatre itself (referring to it as "one of Satan's 'haunts"), Finney recognised that, to appeal to the unsaved, he must replicate what entertained and enticed them (Loveland and Wheeler 2003: 27). The church was in competition with what he deemed the vulgar diversions of the theatre, the sullied sphere of politics, and other worldly distractions. In order to draw audiences away from the secular and back to the spiritual, Finney met would-be believers where they were - using acting techniques and dynamic rhetoric to relate to their cultural sensibilities (Moore 1995: 50). A physical representation of this approach, in $183^{2}$ the fiery preacher held his first service at Chatham Street Chapel, a theatre repurposed into a church in the heart of New York City. Because of its original design, Chatham Street could seat a larger audience, had quality acoustics, and allowed the preacher more freedom of movement than a standard, confined pulpit (Hardman 1987: 252; Loveland and Wheeler 2003: 28). In 1835, Finney moved into the Broadway Tabernacle, a new construction based on his own designs and where he could preach without obstructions. In his estimation, Broadway Tabernacle was an "admirable place for preaching the Gospel, where such

certain consumerism but then also "entered their own inventive contributions into the market". These contributions included print materials, reform activities to rival entertainment culture, and event advertising strategies. Moore notes, "America's boom market in religion operated most effectively at the popular end of the market in cultural commodities".

6 Roger Finke and Rodney Stark (2005: 88-93) compare the tactics of these two ministers, even though they were generations apart, because both relied on revivalism and entertainment to attract converts. 
crowds were gathered within the sound of my voice" (Moore 1995: 314$).{ }^{7}$ The structure could seat twenty-five hundred (or accommodate four thousand including standing room), had an impressive skylight, a gas-lit chandelier, and was built in the round so as to ensure the crowds could see and hear Finney as he gesticulated and roared (Moore 1995: 314). This auditorium church served as a template for later constructions. Its influence can be seen in current megachurches, especially its domed ceiling, circular sanctuary with semi-circular pews, inclined seating, and ample room for choirs and other musicians (Loveland and Wheeler 2003: 38-39). ${ }^{8}$ Broadway Tabernacle changed the standards for church architecture by catering to the comfort of the congregants and ensuring the visibility and centrality of the preacher. Auditorium styles became increasingly popular with evangelical denominations and, by the turn of the nineteenth century, church architects touted the style as 'revolutionary' and 'modern' (Loveland and Wheeler 2003: 44).

Sanctuary designs were not the only element of church architecture and culture that shifted in the nineteenth century. Some congregations so fully accepted entertainment and social life as evangelising necessities that they set aside intentional spaces in the church for Sunday Schools and child care, gymnasiums, kitchens, and even bowling alleys. Mid-nineteenth century reform efforts of churches and their intentional outreach to urban populations resulted in the "multipurpose church" (Loveland and Wheeler 2003: 66-67). These structures linked leisure activities with congregational life to entice city dwellers to join the church community and engage with other believers in a social setting. Dedicated in 1891, the Baptist Temple in Philadelphia became a leading example of this marriage of spiritual and social space. With pastor Russell $\mathrm{H}$. Conwell at the helm, the thirty-five-hundred seat church offered more than the standard religious services; it scheduled youth programmes, concerts, debates, and literary readings for the public. Instead of pews, parishioners sat in opera seats. Below the sanctuary, the church provided 'social rooms', a kitchen, and a dining hall for men, women, and children to fellowship and be entertained (Loveland and Wheeler 2003: 70-79). Additions to programmes and the creation of intentional social spaces at churches like that of Baptist Temple contributed to new directions in church architecture and amenities. Many of these elements can be seen in current megachurches, with some expanding on the

7 The use of the term 'tabernacle' to describe the new church relates back to Whitefield's influence on revivalism and church development.

8 This circular style can be seen in many of the larger, more popular megachurches, such as Lakewood Church, Fellowship Church, Willow Creek Community Church, and Saddleback Church, which are discussed later in the essay. 
multi-purpose design to have buildings detached from the sanctuary and devoted entirely to socialising and entertainment.

\section{$4 \quad$ Mass-Media and Marketing}

At the turn of the nineteenth century, evangelicals became increasingly comfortable with marketing their mission and began to accept the value of entertainment in spurring church membership. "Evangelists believed deeply in the continued relevance of the old-time gospel to the modern world", historian Josh McMullen (2015: 163) notes, "but were keenly aware of these newer impulses of entertainment culture. For this reason, they simultaneously derided and borrowed from the entertainment industry". This entertainment component drew thousands to big-tent revivals in the 1910 s and 1920 s as preachers like Billy Sunday at once rejected amusements such as card playing, dancing, and theatre while at the same time employed similar enticements as the secular market. A former professional baseball star, Sunday converted in the 1886, quit the big league in 1892, travelled as a poor Midwestern itinerant revivalist for years, and became a household name by 1910 (Dorsett 1991). Sunday captivated audiences with his sensational and impassioned performances, in which he used pronounced gestures and, at times, a rough vernacular to relate to and interest viewers (Loveland and Wheeler 2003: 87). Other big tent revivalists used similar antics, but Billy Sunday became a star, with throngs of believers and non-believers flocking to his events. The spectacle of his performance drew them in, as "[e]ntertainment-starved communities turned out in large numbers to hear Billy Sunday if for no other reason than that his meetings offered something entertaining" (Dorsett 1991: 147). From 1908 to 1920, he travelled from city to city in a revival crusade, preaching to at least a million people, and collecting substantial donations in the process (Dorsett 1991: 93). By catering to the average American and intentionally amusing his audiences, Sunday developed a successful formula - a formula that is similar to the seeker-sensitive models of later megachurches.

While Sunday drew thousands under his revival tents, one of his contemporaries used the airwaves to enter the homes and movie theatres of millions more. A Canadian transplant who became wildly popular as a Hollywood religious superstar, Aimee Semple McPherson was the "first religious celebrity of the mass media era", according to historian Matthew Avery Sutton. In his biography of the spiritual starlet, Sutton (2007: 3-4) contends that McPherson's "integration of the latest media tools with a conservative creed established precedents for the twentieth century's most popular ministers, from Billy 
Graham to Oral Roberts to Pat Robertson". While many Americans believed evangelicalism to be on the decline, McPherson saw an opportunity to resuscitate 'old-time religion' through 'show biz', using modern advances in technology, such as radio and film, and patriotism to bolster her cause. ${ }^{9}$ Her pathbreaking proselytising methods laid the groundwork for future Christian radio and televangelism stars who were (and still are) piped into homes from their megachurch pulpits.

In 1923, McPherson merged mass-media and old-time religion in the form of Angelus Temple in Echo Park, Los Angeles, in the heart of the entertainment capital of the United States. Current versions of megachurches - with their light shows, prop-filled mini-dramas, electrified worship music, internet or television audience following from home - owe a degree of their design to the technological savvy, sensationalism, self-promotion, and publicising prowess of Sister Aimee at Angelus. The temple was the central showpiece in McPherson's spiritual empire and where she invested in the innovations that would drive the expansion of her ministry.

Advertising as a faith healer who could pray over the sick and cure their ailments, McPherson engaged in a revival tour and raised enough funds to erect the lavish structure just miles from downtown Hollywood. Seating fifty-three hundred, the church "looked and felt like a theater", with velvet curtains and a stream that flowed into the baptismal font (Sutton 2007: 19-21). ${ }^{10}$ Overhead, clouds crowned the domed sanctuary. The stage housed a choir loft, massive organ, and included enough space for Sister Aimee's 'illustrated sermons', which the audience viewed from lush, upholstered opera chairs. These sermons used props and actors to bring scripture and social lessons to life, unabashedly fusing fundamentalism, preaching, and scripted skits. On one occasion, for example, Sister Aimee appeared as a prosecutor, putting a generic college educator on trial in "Trial of the Modern Liberalist College Professor versus the Lord Jesus Christ". As evidence of the professor's guilt, the skit referenced passages from the Bible and quotes from George Washington and Abraham Lincoln to counter his atheist, socialist claims. The sketch mixed patriotism with Christian belief, a recipe that became a staple of conservative evangelicalism in the twentieth century (Loveland and Wheeler 2003: 101;

$9 \quad$ McPherson's theology did not fall neatly into a denominational category, a characteristic that also aligns her with more recent megachurch pastors. The cornerstone of Angelus Temple reads "Dedicated to the cause of inter-denominational and worldwide evangelism", which proved prescient of the megachurch movement to which her church contributed.

10 Lakewood Church, in Houston Texas, home to the megachurch pastors Joel and Victoria Osteen, has a similar altar, with two streams flowing to frame the choir. 
Sutton 2007: 1-3; Sutton 2014: 105-106). ${ }^{11}$ McPherson set a precedent for later pastors, like Ed Young, Jr., to explore cultural references and to even incorporate some hoke and make-believe to engross their audiences.

Sister Aimee did not confine her message to the grand halls of her Hollywood temple but projected it out to the rest of the nation on the airwaves and silver screen. She wielded new technology like a cudgel to combat secularisation and declension. Some Christians did not welcome this technology for, as Sutton so eloquently explains, they "feared that in dubbing Satan the prince of power of the air, the apostle Paul had foreseen the new medium" (Sutton 2007: 78)..$^{12}$ But McPherson was not afraid. While the secular radio and film industries were mass-marketing sinfulness, she mass-marketed conservative morality. ${ }^{13}$ She raised more money and set up the "Kall Four Square Gospel" (KFSG) station, with the towers standing atop the Angelus Temple dome like spires. Proclaiming the new medium to be a gift from God, she set out to revolutionise America with programming that included Angelus sermons and choir music, children's services, and speeches condemning dance halls, blasting LA politicians, and praising Prohibition (Sutton 2007: 78-81). Other preachers, especially Chicago's Paul Rader, contributed to this trend and established a national following (Abrams 2001: 37). Radio became the primary means of projecting the evangelical message and winning converts, and by 1925 Christian radio blanketed with United States with 63 of the 600 stations owned by churches and additional stations operated by independent fundamentalists (Abrams 2001: 99).

Many preachers experimented with radio but rejected film because it seemed too titillating to be of benefit to believers. "Concerned Christians", Sutton explains, "organized a sustained fight to censor questionable material, tried to ban Sunday Showing, railed against film's influence on audiences, and lamented young people's unseemly behavior in dark theaters" (Sutton 2007: 154). But McPherson rejected these warnings and became the darling of the

11 Many megachurches today use similar plays to illustrate the main points of the sermon. There are also modernised examples of dramatisations of spiritual points or social concerns as megachurches produce films that are projected on overhead screens to entertain and instruct parishioners.

12 LA pastor and Bible Institute of Los Angeles superintendent T.C. Horton was a critique of radio and made one such allusion (Abrams 2001: 36).

13 Sutton (2014: 120) describes the reaction of Christians, particularly fundamentalists, to the film industry. "In the 1920s", he notes, "tens of millions of Americans enchanted by the silver screen attended movies every week.... For fundamentalists tawdry film represented much more than cheap amusement. It too was a sign of the moral depravity that Jesus prophesied for the last days". 
motion picture industry, even founding her own Angelus Productions company. ${ }^{14}$ Channelling her natural showmanship, the celebrity preacher appeared in shorts in the 1930s, donning impressive white robes and decrying the evils of society in her characteristic singsong voice (Sutton 2007: 154-158). The media presence of stars like Sister Aimee and her contemporaries, including Paul Rader and Bob Jones (who both produced their own silent films in the 1920s), paved the way for modern Christian radio and televangelism, which, in turn, promoted larger and more diverse church audiences (Sutton 2014: 122). The celebrity pastors of the 1950 s benefitted from the techniques of this previous generation and gained more access to American households with the advent of Christian television. The sharp sermonising of conservative preachers like Kathryn Kuhlman, Oral Roberts, and Rex Humbard filled the living rooms of more and more Americans as they sat around sets with their TV trays at night (Alexander 1994: 59).

The most famous pastor on television in the 1950s, Billy Graham became the face of the "revival of revivalism", joining with other conservative forces to hold massive youth rallies and promote multi-city crusades (Carpenter 1999: 212). One of these early revival tours covered sacred evangelical ground. His fourweek big tent revival in 1949 drew in celebrity admirers in Los Angeles, home of Aimee Semple McPherson's Angelus Temple. Later that year Graham appeared in Charles Grandison Finney's "burned-over district" of New York and in summer of $195^{\circ}$ his campaign "reached a climax" on Boston Common, where George Whitefield had spread the revival spirit in 1740 (Carpenter 1999: 225229). Quickly becoming the most popular evangelical preacher in the world, Graham honed his preaching skills by listening to and learning from radio announcers, "merging their timing and timeliness with his own passion to save lost souls" (Carpenter 1999: 212). His continued national success resulted from his ability to translate traditional evangelical teachings for a television audience. Leading the way for fellow revivalists, Graham served as a "role model" for the shift to television broadcasting when, in 1950, he organised a revival in a "specially constructed tabernacle" in Portland, Oregon, with equipment to film his sermons and documentary films (Frankl 1987: 73-74). This decision set a precedent for revivalists and megachurch pastors and also ensured Graham's celebrity.

14 McPherson's allure was also derived from the celebrity that the press afforded her after she was kidnapped in 1926 and rumours swirled that she was actually having an affair, despite the lack of evidence to support this theory. She would not be the last megachurch pastor whose career was both mired in (and surreptitiously benefited from) scandal (Sutton 2007). 
From Whitefield's revivalism, McPherson's sensationalism, to Graham's mass meetings and televangelism, modern megachurches have borrowed heavily from their antecedents. Although scholars can trace the lineage of these various megachurch elements to earlier periods, it was not until the 1970s that calculated 'church growth' and 'large church' models directed these elements into the stadium and amphitheatre churches that characterise the current movement. Taking advantage of technological advances, seminary professors and ministers found new formats for evangelising and created an intentional, researched movement for megachurch development. In the same decade that dedicated televangelism networks emerged (Christian Broadcasting, Trinity Broadcasting, and the ill-fated Praise the Lord), Liberty University's Jerry Falwell and Elmer Towns touted the benefits of "large churches" (Bowler 2013: 104-110; Flake 1984: 131-148; Loveland and Wheeler 2003: 114). ${ }^{15}$ One impetus for the 'large church' argument was the success of the post-war 'new revivalism' as represented by organisations like Youth for Christ and the Billy Graham crusades. Thousands attended events in stadiums, auditoriums, concert halls, and under big tents, spaces that revivalists had to use because most churches did not have the capacity to hold the numbers they hoped to attract. Falwell and Towns's theory was simple: if churches could hold thousands, they could minister to thousands. If churches had more sanctuary space and were better appointed, included facilities for other services like schools, counselling, and recreation, they would attract more souls. Reminiscent of multipurpose churches like Comwell's Baptist Temple, the vision for these churches was to meet the needs of the community but on a much larger scale than before (Loveland and Wheeler 2003: 114-115).

If built to these standards, churches could certainly hold more attendees, but ministers and their staff also had to entice and retain them. From the 1970s to the 1990s, seminary professors and pastors articulated 'church growth strategies' that would encourage higher turnout by church branding and marketing churches to a new generation of potential believers. Dean and professor at Fuller Theological Seminary's School of World Mission, Donald A. McGavran introduced his concepts of church growth in the 1960 s to fellow evangelicals, who expanded on his designs in subsequent decades (McGavran 1970;

15 It is important to note that megachurches are not all fundamentalist or conservative, mainline or dissenting, denominational or non-denominational. The trends of mass media messaging/marketing, large church, and church growth have been used by churches across the evangelical spectrum. 
McIntosh 2005). A former missionary to India, McGavran developed his perspective while testing and observing what strategies worked in the mission field. Other professors at Fuller, including C. Peter Wagner, followed suit and conducted their own studies, generating publications, seminars, and conferences to promote the rapid expansion of church congregations (Bowler 2013: 101-102; Loveland and Wheeler 2003: 115-117). ${ }^{16}$

The methods that church-growth experts promoted mirrored previous evangelical efforts to make faith relevant to the average American (Moore 1995; Scalen, Jr. 2008; Twitchell 2007). They did not want churches to look backwards, however, and return to an 'old-time religion', but to use technology and marketing research to create an 'innovative' church experience. These innovations were aimed at the unchurched - Americans who had no church home or denominational devotion and nonbelievers. Pulling the curtain back and directly addressing the capitalist, commercial nature of the religious marketplace, church growth experts spoke openly about their place in consumer culture. Comparing churches to shopping malls, they argued that Americans are more likely to drive to giant gallerias that have food courts and other services than to boutique shops or strip malls that have fewer options. Larger churches with more amenities are what potential parishioners are seeking and what evangelical leaders need to provide if they hope to sell the church and save the soul. Innovative churches are thus 'market-driven', with "target audiences" whose "lifestyle, needs, and desires" are discovered through "demographic and market research" (Loveland and Wheeler 2003: 117-118).

Taking his cues not from drive-in theatres and shopping malls, Robert H. Schuller developed one of the earliest examples of a market-oriented, advertising-focused ministry. Ordained by the Reformed Church in America, Schuller broke away from typical church-planting strategies and performed his own market research in Orange County, California, to determine what his church could offer to attract attendees. The young pastor went from door to door in local neighbourhoods to ask why residents did not attend church. Applying what he learned from this canvassing, Schuller tested his marketing strategies in 1955 when he set up services at a drive-in movie theatre, boasting that anyone could come "as you are in your family car!" (Loveland and Wheeler 2003: 117-120). His approach was successful and, by 1961, his efforts brought in enough funds to construct the three-million-dollar Garden Grove Community

16 Church growth experts at Fuller included C. Peter Wagner, Carl F. George, and John Wimber. Elmer Towns of the 'large church' movement also gravitated to church growth models, as did pastor Robert H. Schuller (Crystal Cathedral), Bill Hybels (Willow Creek Community Church), and Rick Warren (Saddleback Church). 
Church that could be seen from the nearby freeway. The unique layout allowed him to preach to congregants inside and, by shifting a glass wall and amplifying the sound, additional attendees in their cars in the parking lot. Combining recreational drive-in culture with radio evangelism, Schuller broadcast his sermon so that cars in the farther reaches of the lot could tune in while they watched him on stage (Loveland and Wheeler 2003: 119). In 1974, Schuller published a church growth manual, Your Church Has Real Possibilities!, detailing to other pastors how they could find similar success. He argued that evangelicals should build churches that appeal to people who did not grow up going to Sunday services - people who might have never set foot in a sanctuary. This formula worked and in 1980, Schuller's ministry completed construction on the famous Crystal Cathedral, a physical testimony to his church-growth mindset. He described it as a "22-acre shopping center for Jesus Christ" (Loveland and Wheeler 2003: 153). Made for TV, its impressive, modern design conveyed affluence, incorporated few religious symbols, and was intended to 'relax' the audience (both in person and watching from home). It, too, had space for the 'drive-in' gimmick that defined Schuller's brand and was equipped with a stateof-the-art system for the widely viewed The Hour of Power television broadcast (Bowler 2013: 103-104; Loveland and Wheeler 2003: 153-154).

Eager to learn how to grow his own congregation, in 1976 a young Bill Hybels found himself on a top floor of Schuller's Tower of Prayer at the Garden Grove Church, face to face with the famous minister. In what Hybels deemed a "divinely staged encounter", Schuller advised the upstart pastor to think big. The more land he can buy and the larger the building he can erect, the more opportunity Hybels would provide God to bless the church with congregants. "If God chooses to do a miracle", he insisted, "you'd better be ready for it" (Hybels and Hybels 1995: 69). At that time, Hybels, his wife, and his staff were looking for a location to plant Willow Creek Community Church, which had no permanent home at the time but met in various locales including a rented theatre. But Schuller encouraged them to build something for God to fill - to anticipate the miracle (Hybels and Hybels 1995: 67-70). Hybels did just that. In 1981, the co-founder of the giant Son City youth group applied the lessons he learned from that ministry and the advice from Schuller to begin preaching 'seeker' services in a seven-thousand seat auditorium (Hybels and Hybels 1995; Loveland and Wheeler 2003: 121-122). Unlike the opulent, awe-inspiring Crystal Cathedral with its 10,900 window panes, Willow Creek looked more like a clean sterile corporate complex. This architectural style was the neutral, contemporary look is meant to reflect the 'values' of middle and upper middle class suburbanites familiar with "Disney World and first-class hotels" (Loveland and Wheeler 2003: 123, 153). Adapting church-growth models to the unchurched 
market in South Barrington, Illinois, Willow Creek experimented with (and then trained others in) a 'seeker-sensitive' approach to worship and church management. Casual, rocking, and culturally relevant, these services sought to transform the evangelical experience for skeptics. "The music was loud", Lynn Hybels remembered, "the drama was raucous (sometimes crossing the line of acceptability), and Bill walked onto the stage with no notes, no pulpit" (Hybels and Hybels 1995: 62). This worship format influenced other churches who were searching for a way to relate to similar local constituents and to potentially bring in thousands of new followers (Sargeant 2000: 9).

'Seeker-Sensitive' Churches

With dynamic skits that pulled in popular culture, an electrified band to lead worship music, and a jean-clad pastor who rejected formal sermons, Willow Creek reached the unchurched in an unconventional and highly effective way. By 1990, the church boasted a record 15,200 in weekend attendance (Hybels and Hybels 1995: 107). ${ }^{17}$ By 1992, with other church leaders clamouring for 'seeker-sensitive' training, the church established the Willow Creek Association (WCA) to hold conferences, distribute resources, and offer consulting for megachurches and mega-wannabes. The wCA represented a shift in American Protestant organisation away from a focus on structured denominationalism and towards a non- and inter-denominational conference network (Sargeant 2000: 137-148). While some megachurches still associate with denominations, most conceal overt symbols and, instead, opt for the more corporate branding that worked for seeker churches like Willow Creek.18 By 2000, wCA had more than five thousand members, connected not by doctrinal or institutional ties but by marketing and methodology (Sargeant 2000: 134-162).

By the time he took the stage at the 1997 WCA 'Leadership Summit', pastor Rick Warren had already made his mark on the seeker-sensitive model. A graduate of Fuller Theological Seminary, Warren adopted Hybels's seeker sensibilities, researched the Orange County market, and built a church there that resembled a theme park more than a temple or tabernacle (Sargeant 2000: 4-5). In the 1980s, this innovative 'pastorpreneur' established the 'Saddleback Strategy', that "targeted unchurched, well-educated, professional Baby Boomers who felt uncomfortable in the "traditional church"' (Loveland and Wheeler

17 For an excellent study of rock 'n' roll precursors to seeker worship music, see Stephens (2018).

18 Internet site, http://hirr.hartsem.edu/megachurch/definition.html. Accessed 9/8/2018. 
2003: 150). In 1979, he scrapped his Baptist seminary-style sermons and canvassed neighbourhoods (as Schuller had done about two decades prior) to discover what would draw unbelievers and jaded believers to his church. Responding to feedback that potential churchgoers preferred anything but traditional denominational form and ritual and restrictions, Warren established Saddleback Valley Community Church, which met in a high school gymnasium (Wilford 2012: 9). Relying on the survey data, he decided to conceal the church's Baptist associations and to focus instead on more neutral, positive, self-help sermons (Ellingson 2007: 212n25). Within three years, he had an active church membership and, by 1989, the church had raised enough money to move into a tent that seated 2,300 (Lee and Sinitiere 2009: 140-141).

Warren continued to develop his version of seeker sensitive at Saddleback, and it continued to pay off. More shorts and t-shirt wearing parishioners poured in each year to hear the relatable preacher share common-sense spiritual lessons and words of encouragement. Saddleback hit its stride in the 1990s by offering "therapeutic and easily accessible sermons, producing high-quality and cutting-edge worship services, and promoting and maintaining small groups" (Wilford 2012: 10). By dividing the thousands of members into smaller study and support groups, Warren and his team found a way to provide structure to retain and grow seekers that other large churches would begin to emulate. With its friendly atmosphere and affirming messages, Saddleback discovered a winning formula. In 1995, the congregation moved to its current location on a hilltop with 120-acres of land on which they constructed a sprawling church campus that attracts over 22,000 attendees each weekend (Hartford Institute for Religion Research; Lee and Sinitiere 2009: 142). ${ }^{19}$ Designed by theme-park specialists, the complex includes separate buildings for different group meetings and activities: an auditorium for worship, two baptism pools, cafes, a children's building and a nursery, and multiple ministry office buildings. ${ }^{20}$ A newer addition for youth called 'The Refinery' features a volleyball court, pizza parlor, basketball court, performance space, televisions, pool tables, and video games (Jelden 2009).

Like other church-growth experts, Warren embraced consumerism and entertainment as the logical way to reach potential church customers. "People will drive past all kinds of little shopping centers to go to a major mall", he reasoned, "where there are lots of services and where they meet their needs. The same is true in churches today in that people drive past dozens of little

\footnotetext{
19 Internet site, http://hirr.hartsem.edu/cgi-bin/mega/db.pl?db=default\&uid=default\&view _records $=1 \& I D=* \& s b=1$. Accessed 9/10/2018. This figure was last updated in 2010.

Internet site, https://saddlebackworship.com/map/. Accessed 9/10/2018.
} 
churches to go to a larger church which offers more services and special programs" (Loveland and Wheeler 2003: 117). Like the various areas of theme parks like Disney World, Saddleback includes ten venues that have services with different flavours - jazz, reggae, punk rock - to cater to attendees' preferences (Lee and Sinitiere 2009:143). Like Schuller's drive-ins but with modern, hi-tech speakers and video, Warren's voice is amplified throughout the complex and his image projected onto screens in each of the worship tents and pavilions. To further engage worshippers, the sermons piped into the worship centres are patterned after the "emotional beat chart" used by the film industry to help drive the narrative and illicit audience response (Lee and Sinitiere 2009: 142-144).

The most influential seeker-sensitive pastors, Hybels and Warren cast the mould for suburban/exurban megachurch planning and marketing. The same year that Saddleback moved to the hilltop, Warren released The Purpose Driven Church (part of his highly successful 'purpose-driven' series), to help guide other congregations to megachurch status. Referencing McGavran's original church-growth argument, Warren pronounced what could be the megachurch credo: "God wants his church to grow; he wants his lost sheep found!" (Ellingson 2007: 69-70; Warren 1995). More pastors and church organisations internalised this message and adopted the seeker-sensitive approach, rejecting denominational trappings and tapping popular entertainment culture to fill their pews (or theater seating) with suburban and exurban flocks. As a result, the 1990s saw a boom in seeker churches that advertised themselves as "not your typical church" in an attempt to distance themselves from "traditional" denominational churches with staid sermons and hymns (Thumma and Travis 2007: 39-40, 58). These churches reflect a 'new paradigm' in Protestant church development that signals a move away from established religion in a "revolution" that "is transforming American Protestantism" (Miller 1997: 1-2). Seeker congregations are just one format (generally the largest one) for these new paradigm churches that are "appropriating contemporary cultural forms.... restructuring the organizational structure of institutional religion.... " and are "democratizing access to the sacred by radicalizing the Protestant principle of the priesthood of all believers" (Miller 1997:1). With an entertainment-driven approach to worship, preaching, and church-building, these churches counter a decline in church attendance by appealing to prospective members through "polished music, multimedia, and sermons referencing popular culture and other familiar themes" (Branaugh 2008). ${ }^{21}$ They replaced organs with electric

21 In 2007, Willow Creek released its Reveal: Where Are You? (Hawkins and Parkinson) study that provided information from surveys of the congregation. Many newer churchgoers 
guitars and drum booths. They encouraged casual clothing over suits and skirts (Watson and Scalen 2008). And at least one suspends a giant fake shark behind its pastor for one week a year.

\section{7}

\section{Conclusion}

While some seeker-sensitive churches like Willow Creek and Saddleback focused on the church brand to market the faith and expand their ranks, other congregations grew rapidly because of their promotion of celebrity pastors. Some pastors like Hybels and Warren did not desire television fame and did not pursue broadcasts or personal recognition (Thumma and Travis 2007: 58). But others openly and directly connect their personal image to the prosperity of their churches, leading to one of the most visible megachurch phenomena: the personality-driven growth model. Since the 1990s and especially in the new millennium, Americans have witnessed a proliferation of celebrity pastors who hawk self-help books, tweet inspirational insights, stream internet broadcasts, and soak up prime Christian television spots. This contingent of famous mega-personalities has helped define the rise of massive churches and has contributed to their depiction in American popular culture (Flake 1984; Twitchell 2007). Like predecessors such as Aimee Semple McPherson, these popular preachers carefully craft their images and project them to a broad audience through mass media. Modern megachurch entrepreneurs, however, have seemingly unlimited platforms for reaching millions via social media and international evangelical programming. These churches are 'pastor-focused', according to Thumma and Travis (2007:57), as "[m] uch of the identity of these congregations is formed around the vision and passion of this founding minister, and few have undergone pastoral transitions". Prominent examples of these late-twentieth and early-twenty first century include Paula White at New Destiny Christian Center in Apopka, Florida; Creflo Dollar of World Changers Ministries in College Park, Georgia; T.D. Jakes of the Potter's House in Dallas, Texas; and, the smiling face of the largest megachurch in the United States, Joel Osteen at Lakewood Church in Houston, Texas.

Ed Young, Jr., is one of these celebrity pastors. His predecessors likely never envisioned the kind of innovations that Fellowship Church and megachurches

expressed little spiritual growth with the format of the seeker services and Willow Creek revamped its approach to offer more instruction and depth. Branaugh explains this shift at Willow Creek in his article for Christianity Today. 
like it experiment with each week. His 'Shark Week' series, rap videos, or sensational 'Sextember' sermons preached from a bed to encourage married couples to renew their passion, would have startled previous pastors like Whitefield, Finney, and Graham. But the foundation that these earlier revivalists and evangelists laid served as a firm base for the construction of Fellowship Church and other massive, arena-style churches around the world. These earlier examples of tabernacles, amphitheatre churches, and multi-purpose temples illustrate the pioneering and market-oriented spirit of evangelicalism that has ultimately led to explosion of high-tech megachurches that define the contours of Protestantism today (Loveland and Wheeler 2003: 178-179). Modern megachurches represent a new form of corporate, technologically driven, and consumer-directed religion that borrowed from these past forms and evolved through the use of mass-media and church-growth strategies. They have embraced innovation and secular, cultural influences to rapidly expand their numbers and the reach of their messages. These corporate churches with millions of followers could not have achieved such substantial success without a firm foundation laid by pioneer pastors before them who experimented with preaching styles, adapted to cultural trends, and revolutionised evangelical religion.

\section{References}

Abrams, D.C.. 2001. Selling the Old-Time Religion: American Fundamentalists and Mass Culture, 1920-1940. Athens: University of Georgia Press.

Alexander, B.C. 1994. Televangelism Reconsidered: Ritual in the Search for Human Community. Atlanta, GA: Scholars Press.

Benes, P. 2012. Meetinghouses of Early New England. Amherst: University of Massachusetts Press.

Bowler, K. 2013. Blessed: A History of the American Prosperity Gospel. New York: Oxford University Press.

Branaugh, M. 2008. "Willow Creek's 'Huge Shift." Christianity Today. At https://www .christianitytoday.com/ct/20o8/june/5.13.html. Accessed 7/1/18.

Carpenter, J.A. 1999. Revive Us, Again: The Reawakening of American Fundamentalism. New York: Oxford University Press.

Dorsett, L.W. 1991. Billy Sunday and the Redemption of Urban America. Grand Rapids: William B. Eerdmans Publishing Company.

Eagle, D.E. 2015. "Historicizing the Megachurch." Journal of Social History. 48:3, 589-604. 
Ellingson, S. 2007. The Megachurch and the Mainline: Remaking Religious Tradition in the Twenty-first Century. Chicago: The University of Chicago Press.

Fellowship Church. At https://fellowshipchurch.com. Accessed 7/1/18.

Finke, R. and Stark, R. 2005. The Churching of America, 1776-2005: Winners and Losers in Our Religious Economy. New Brunswick: Rutgers University Press.

Flake, C. 1984. Redemptorama: Culture, Politics, and the New Evangelicalism. Garden City, NY: Anchor Press.

Frankl, R. 1987. Televangelism: The Marketing of Popular Religion. Carbondale: Southern Illinois University Press.

Hardman, K.J. 1987. Charles Grandison Finney, 1792-1875: Revivalist and Reformer. Syracuse: Syracuse University Press.

Hartford Institute for Religion Research. 2012. "2012 Profile of All North American Megachurches." At http://hirr.hartsem.edu/megachurch/megastoday_profile.html. Accessed 8/28/18.

Hartford Institute for Religion Research "Database of American megachurches." At http://hirr.hartsem.edu/cgi-bin/mega/db.pl?db=default\&uid=default\&view _records $=1 \& \mathrm{ID}={ }^{*} \& \mathrm{sb}=\mathbf{1}$. Accessed $9 / 10 / 18$.

Hatch, N.O. 1989. The Democratization of American Christianity. New Haven: Yale University Press.

Hawkins, G.L. and Parkinson, C. 2007. Reveal: Where are You? Barrington, IL: Willow Creek Resources.

Hybels, B. and Hybels, L. 1995. Rediscovering Church: The Story and Vision of Willow Creek Community Church. Grand Rapids, MI: Zondervan Publishing House.

Jelden, I. 2009. "Faith in the Valley: The Refinery." The Orange County Register. At https://www.ocregister.com/2009/02/05/faith-in-the-valley-the-refinery/. Accessed on $9 / 10 / 18$.

Lambert, F. 2008. Religion in American Politics: A Short History. Princeton: Princeton University Press.

Lee, S. and Sinitiere, P. 2009. Holy Mavericks: Evangelical Innovators and the Spiritual Marketplace. New York: New York University Press.

Loveland, A.C. and Wheeler, O.B. 2003. From Meetinghouse to Megachurch: A Material and Cultural History. Columbia: University of Missouri Press.

McGavran, D.A. 1970. Understanding Church Growth. Grand Rapids, MI: Wm. B. Eerdmans Publishing Company.

McIntosh, G.L. 2005. “The Impact of Donald A. McGavran's Church Growth Missiology on Selected Denominations in the United States of America, 1970-200o." PhD. Fuller Theological Seminary School of World Mission, Pasadena, CA.

McMullen, J. 2015. Under the Big Top: Big Tent Revivalism and American Culture, 1885-1925. New York: Oxford University Press. 
Miller, D.E. 1997. Reinventing American Protestantism: Christianity in the New Millennium. Berkeley: University of California Press.

Moore, R. 1995. Selling God: American Religion in the Marketplace of Culture. New York: Oxford University Press.

Sargeant, K.H. 200o. Seeker Churches: Promoting Traditional Religion in a Nontraditional Way. New Brunswick: Rutgers University Press.

Schuller, R.H. 1974. Your Church Has Real Possibilities! Glendale, CA: G/L Regal Books.

Stephens, R.J. 2018. The Devil's Music: How Christians Inspired, Condemned, and Embraced Rock ' $n$ ' Roll. Cambridge: Harvard University Press.

Stout, H.S. 1991. The Divine Dramatist: George Whitefield and the Rise of Modern Evangelicalism. Grand Rapids, MI: Wm. B. Eerdmans Publishing Company.

Sutton, M.A. 2007. Aimee Semple McPherson and the Resurrection of Christian America. Cambridge: Harvard University Press.

Sutton, M.A. 2014. American Apocalypse: A History of Modern Evangelicalism. Cambridge: The Belknap Press of Harvard University Press.

Thumma, S. and Travis, D. 2007. Beyond Megachurch Myths: What We Can Learn from America's Largest Churches. San Francisco: Jossey-Bass.

Twitchell, J.B. 2007. Shopping for God: How Christianity Went from in your Heart to in Your Face. New York: Simon and Schuster.

Warren, R. 1995. The Purpose Driven Church: Every Church is Big in God's Eyes. Grand Rapids, MI: Zondervan Publishing Company.

Watson, Jr., J.B. and Scalen, W.H. Jr. 2008. "Dining with the Devil': The Unique Secularization of American Evangelical Churches." International Social Science Review. 83: $3,171-180$.

Wilford, J.G. 2012. Sacred Subdivisions: The Postsuburban Transformation of American Evangelicalism. New York: New York University Press.

Young, Jr., E. 2011. "Swimming with Sharks." Ed Young Sermons. At http://edyoung sermons.com/sermon/swimming-with-sharks. Accessed 7/1/18. 